\title{
A Study on Energy Crisis and Social Benefit of Solar Energy
}

\author{
Srinivasan Chinnammai
}

\begin{abstract}
Growing consumption of energy has also resulted in the country becoming increasingly dependent on fossil fuels such as coal, oil and gas. Rising prices of oil, gas and coal and potential shortages in future lead to concerns about the security of energy supply needed to sustain our economic growth. Increased uses of fossil fuels have also caused environmental problems both locally and globally. Against this background, the country urgently needs to develop a sustainable path of energy development.

The ultimate solution for the secure supply of energy will be the discovery of methods of harnessing non-conventional energy sources. The extraction and utilization of non-conventional energy will not only help in meeting energy demands but also help in their development. Since non-conventional energy sources provide environment-friendly, non-polluting energy, they help keep the atmosphere and environment clean and safe. Moreover, such energy sources are available locally; therefore they will reduce the losses due to transmission. Hence this paper examines the short fall of energy and also it is find out the social benefit of the solar energy utilization.
\end{abstract}

Index Terms - Conventional energy, electricity, power, solar energy.

\section{INTRODUCTION}

Energy is the basic necessity for life. But for energy no form of life would have ever emerged. We all know energy for providing us light and comfort. It can help us to cool down during summers and feel warm during winters. It also helps us to go from one place to another. All automobiles need energy to run; but even otherwise all other means of transport need energy. But even though we use it every moment of our life and learn about it at school it often remains a riddle for many all through the life. An energy crisis is any great bottleneck (or price rise) in the supply of energy resources to an economy. In popular literature though, it often refers to one of the energy sources used at a certain time and place, particularly those that supply national electricity grids or serve as fuel for vehicles. There has been an enormous increase in the global demand for energy in recent years as a result of industrial development and population growth. Supply of energy is, therefore, far less than the actual demand. An energy crisis is a situation in which a nation suffers from a disruption of energy supplies connected by increasing energy prices that threaten economic and national security. At the moment, there is an increasing worldwide demand for electrical power and transportation, both which depend mostly on fossil fuels, such as oil

Manuscript received September 3, 2013; revised December 4, 2013.

Srinivasan Chinnammai is with the Department of Economics, University of Madras, Chennai (e-mail: pragathauom@gmail.com) products. Because the population and new technology is always expanding, demand for energy is expected to increase year by year. With ninety percent of the world's oil reserves already discovered, people need to find new ways to make energy. The energy crisis of this new century needs charge, attention, and a change that will keep the country running on more than just fumes. Renewable energy has huge potential to already discovered, people need to find new ways to make energy. The energy crisis of this new century needs charge, attention, and a change that will keep the country running on more than just fumes. Renewable energy has huge potential to provide solution to increase energy crisis and it is the key factor to the future of energy, food and economic security.

The solar energy technology, a novel technology for the people, provides superior energy for cooking, lighting and many other purposes. There are divergent opinions regarding the application of solar energy as the best alternative as well as renewable source of energy. Accordingly different persons including scientists, technocrats, economists, etc. view solar energy from multiple angles. It is in this background that an attempt has been made to review the literature on the subject of solar energy, to understand the varied perspectives on conventional energy scenario, power development and its present position, and to understand renewable energy in general terms and solar energy in particular.

Numerous studies have been conducted and various works have been published in the field of conventional energy, power sector, renewable energy and solar energy in India and abroad. These studies throw light on the various analytical angles viewed by Indian and foreign authors. Their studies investigate the present energy and power scenario and its related sectors, and this research study has tried to analyze the various recommendations suggested by them. Thus, for the purpose of an analytical research, various books, journals, magazines and dailies are reviewed under.

\section{A. Review of Literature}

Muhopadhyay et al. (1993) have done a comparative study of solar PV presented against a kerosene lantern for a life period of 25 years. This centralized charging system with solar PV provides self-employment and economical feasibility. A proper design and fabrication of the central charging station along with matching portable solar PV lantern has also been discussed in detail. This approach for central charging of the PV lanterns appears to be reliable and provides cost effective lighting to rural sectors especially in developing countries [1].

Kumar et al. (1996) have estimated that India is endowed with abundant solar energy resource. The average intensity of solar radiation received in India is $200 \mathrm{MW} / \mathrm{km}$. Even if 10 percent of the available area can be used, the available solar 
energy would be $8-$ million mega watts. This is equivalent to 5909 million tones of energy per year. Considering the ever-increasing demands of the country, this resource can be gainfully utilized, especially for meeting the electrical needs of rural poor, who are not likely to be served by the grid; and for meeting thermal energy requirements of domestic, industrial and commercial sectors. He has stated that in the last three decades, a lot of developmental work was carried out in India, in the field of solar thermal and solar photovoltaic technologies [2]. Chopra S.K. (2004) has outlined the strategy of Integrated Energy Policy which encapsulated the energy security of our country in totality. He has gone beyond fossil fuels to focus on cow-dung, firewood and agricultural waste on which vast sections of our population, particularly the rural population overwhelmingly depends. He also has dealt with different energy sub-sectors, including electricity, coal, petroleum and natural gas and renewable energy. In this study he has provided a separate section to focus on rural energy in all its forms and uses. Rural energy is especially important for India and other developing countries because it affects the lives of over seventy percent of the country's population.

He has provided the background, justification and design for an Integrated Sustainable Energy policy for the country for the next two decades towards which mankind will eventually turn to for its very survival and its future. Environmental concerns in the energy sector have also been discussed in detail in a separate section. These include both local and environmental issues, including India's commitment to various international conventions on environment. Relying on the latest scientific information, this report has explored the various scenarios for future energy demand, and their implications. It has recommended the introduction of rational planning where market economics obstruct environmentally sound, long-term choices [3].

Bani P. Banerjee (2005) has pointed out the logistical and economic problems involved in satisfying the expanding energy needs of the world population and of closing the gap between the energy consumption of the richest industrial nations and the poorest agricultural nations. He has stated that rapid and unconstrained expansion in energy demand could hit supply constraints, especially of oil and natural gas; he has also discussed the energy and environmental problems of India against the backdrop of energy planning concepts and policy instruments [4].

Manmohan Singh (2009), India's Prime Minister, has stated that government seems to have made the capacity-addition target more realistic through a mix of sources, coal, hydel, nuclear and renewable; by the end of the Eleventh Five Year Plan (2007-12) the government would be able to add about 52,000 MW of new capacity, a 34\% drop from the original target of 78,600 MW [5].

Pratibha Patil (2009), then President of India, has said that total capacity addition in the first two years of the $11^{\text {th }}$ plan, was $12,700 \mathrm{MW}$ against a target of about 23, $100 \mathrm{MW}$. The year 2008-2009 was among the worst, with generation addition of a mere 3,500 MW, 68\% less that the targeted addition of $11,061 \mathrm{MW}$. She has stated that with the downward revision of capacity addition targets may act as a spanner to achieve power for all by 2012. It is clear that the government is expected to frame policy that will outline effective use of various forms of energy such as coal, nuclear power, crude oil, natural gas, wind and solar power in the years to come [5].

\section{MethodologY}

The present study is empirical, based on both primary and secondary sources of data. The framework of the analysis has been constructed from the data collected through primary surveys by interview schedules and field visits covering Chennai and Thiruvallur districts. Secondary data, regarding net availability of power, distribution of power supply under state and all-India level have been collected from administrative reports, planning commission reports, books etc. These data have been used to highlight and substantiate the theoretical aspects of the solar power distribution. An attempt has been made to focus on the solar power sector growth and distribution in the study area.

\section{A. Objectives of the Study}

1) To evaluate short fall in energy production

2) To find out the factors for affecting the performance of power sector

3) To examine the motivational factor for the utility of solar energy.

4) To analyze the exact benefits of solar energy in the study area.

\section{B. Hypotheses of the Study}

There is no significant difference in benefits accrued by using two types and 500 LPD sizes of solar water heaters.

\section{Sample Selection}

The total sample size is 592, of which 296 consists of users of solar energy devices and 296 samples consists of non-users of solar energy devices. For selection of samples, the purposive sampling technique has been adopted. Purposive sampling has been deliberately used in the place of popular methods such as multi-stage stratified random sampling technique. The researcher tries to probe into sustainable energy features therefore, this study attempts to find out whether solar energy devices are economically viable to the users. It tries to throw light on the cost of solar energy devices like solar water heaters and its benefits to households and corporate. Hence primary data has been collected through interview and questionnaire methods.

\section{Statistical Tools}

Social Cost Benefit Analysis

Cost: cost depends upon the capacity of the module, brand and the type of solar device.

Fixed cost $(\mathrm{FC})+$ Recurring Cost $(\mathrm{RC})$

$\mathrm{FC}=($ cost of the module + installation cost $)$

$\mathrm{RC}=$ (maintenance cost)

Benefits: benefits are measured in terms of units of electricity saved on using solar devices when compared to other electrical appliances.

The discount factor is

$$
D=1 /(1+i) t
$$


where $i=$ social discount rate, $t=$ time period.

To check the feasibility of the modules the following techniques were adopted in the present study.

1) Payback Period

Payback period = Initial investment/ Annual cash in flow

2) Benefit Cost Ratio

\section{Benefit cost ratio $=$ Benefits $/$ Cost}

3) Net Present value

Net present value $=$ Discounted benefit - Discounted cost

4) Internal Rate of Return

Internal rate of return $=($ Net Annual Benefits $/$ Capital investment) (100)

\section{RESUlT AND DISCUSSION}

The power development in the country entered an era of planned development in the year 1951-52 when the first five year plan was launched. The Electricity (supply) Act 1948 was formulated with the objective of re-orienting the power supply industry to meet developmental needs of the country. The subject 'power' is in the concurrent list of the constitution and as such the responsibility of its development lies both with the central and state governments. Hence power generation and development is a joint responsibility of both the State and Central Government in India. The power industry system is operated by eighteen State Electricity Boards (SEBs), which are again formed into five Regional Boards.

The allocation for power development was unfortunately low during the first four plans, between 10 to 15 percent of the total outlay. The low priority given to power development was sought to be justified at that time, on the ground that industries had not come up so fast and that progress in rural electrification and in the use of electric power in the railway transport system was inadequate and did not need much investment. This proved to be a wrong judgment on the part of the planners. With rapid industrialization and extensive demand for power both in rural and urban areas, the country has been reeling under severe power shortages and the countries production effort has been severely curtailed by load shedding almost in all parts of the country. Even in the $5^{\text {th }}$ plan 19 percent of the total outlay was allocated. In the $6^{\text {th }}$ and $7^{\text {th }}$ plans the allocation for power was raised rather steeply to 28 percent of the total outlay. But this has come too late and power shortage has become a serious constraint to economic development in India. The Ninth and Tenth Five-Year Plans allocated 27 percent of the outlay.

This indicates that a major thrust was given to the development of energy and power by enhancing the public expenditure in this sector. So the share of energy sector in the total public sector outlay has been increasing over the various Plan periods with the power sector accounting for the major part [6]. The Table I has analyzed the targets, achievements and shortfalls of energy in India.

Table I shows that in every five year plan there was a shortfall in achievement -15 percent in the first plan and as much as 51 percent in the fourth plan. The cumulative result of slackness in this basic area of planning is that power crisis threatened to choke the growth process of the Indian economy. It delayed the further development of the energy sector in the next two plans, namely fourth and fifth plans. Accordingly, the sixth plan (1980-85) put maximum emphasis on power generation; even then, there was a shortfall of 28 percent in the power generation target. The short-fall of 3 percent during the seventh plan period was the lowest. The power generation fell much below the original target of 30,538MW and 40,245 MW during the $8^{\text {th }}(1992-$ $97)$ and also $9^{\text {th }}$ plan periods $(1997-2002)$ respectively. During the $9^{\text {th }}$ plan period, the achievement was less than 50 percent of the respective target and the shortfall in the Ninth plan was a hefty 53 percent. Even during the $10^{\text {th }}$ plan period (2002 -07) power generation had not achieved its target and fell short of 43 percent.

In the $11^{\text {th }}$ plan $(2007-12)$ the Planning commission has set the target of $62,000 \mathrm{MW}$ capacity addition, but the Prime Minister's Energy Co-ordination Committee (ECC) registers its dissatisfaction on this target and has pointed out that sustaining an 8-9 percent economic growth would require a capacity addition of 75,000 MW if capacity addition backlog in the $10^{\text {th }}$ Plan (2002 -07) was taken into account. The recommended target of ECC is 13,000 MW more than the $62,000 \mathrm{MW}$ projection made for the next plan period [7].

In order to get a better insight into the shortfall of electricity, it is necessary to know the factors which affect the power supply.

TABLE I: TARGETS ACHIEVEMENTS AND SHORTFALLS IN Five YEAR PLANS

\begin{tabular}{|l|l|l|l|l|}
\hline $\begin{array}{l}\text { Five Year } \\
\text { Plan }\end{array}$ & Target & Achievement & $\begin{array}{l}\text { Short } \\
\text { fall }\end{array}$ & $\begin{array}{l}\text { Short } \\
\text { fall } \\
(\%)\end{array}$ \\
\hline $\begin{array}{l}\text { First Plan } \\
(1951-56)\end{array}$ & 1,300 & 1,100 & 200 & 15 \\
\hline $\begin{array}{l}\text { Second Plan } \\
(1956-61)\end{array}$ & 3,500 & 2,300 & 1200 & 34 \\
\hline $\begin{array}{l}\text { Third Plan* } \\
(1961-66)\end{array}$ & 7,000 & 4,500 & 2500 & 36 \\
\hline $\begin{array}{l}\text { Annual Plan ** } \\
(1966-69)\end{array}$ & 5,430 & 4,120 & 1310 & 24 \\
\hline $\begin{array}{l}\text { Fourth Plan* } \\
(1969-74)\end{array}$ & 9,300 & 4,600 & 4700 & 51 \\
\hline $\begin{array}{l}\text { Fifth Plan } \\
(1974-79)\end{array}$ & 12,499 & 10,202 & 2297 & 18 \\
\hline $\begin{array}{l}\text { Annual Plan ** } \\
(1979-80)\end{array}$ & 2,945 & 1,799 & 1146 & 39 \\
\hline $\begin{array}{l}\text { Sixth Plan } \\
(1980-85)\end{array}$ & 19,670 & 14,230 & 5440 & 28 \\
\hline $\begin{array}{l}7^{\text {th }} \text { Five Year Plan } \\
(1985-90)\end{array}$ & 22,250 & 21,500 & 750 & 3 \\
\hline $\begin{array}{l}8^{\text {th }} \text { Five Year Plan } \\
(1992-97)\end{array}$ & 30,540 & 16,420 & 14120 & 46 \\
\hline $\begin{array}{l}9^{\text {th }} \text { Five Year Plan } \\
(1997-2002)\end{array}$ & 40,250 & 19,015 & 21235 & 53 \\
\hline $\begin{array}{l}10^{\text {th }} \text { Five Year Plan } \\
(2002-07)\end{array}$ & 41,110 & 23,250 & 17860 & 43 \\
\hline $\begin{array}{l}11^{\text {th }} \text { Five Year Plan } \\
(2007-12)^{* * *}\end{array}$ & 62,000 & - & - & - \\
\hline
\end{tabular}

Source: *Datt \& Sundharam (2010) 'Indian Economy' Chand \& Company, New Delhi, pp129.\& ** Ministry of power, Annual Report (1966-69, 1979-80); *** Panorama Year Book '2007, PP.184. 


\section{Factors Affecting the Performance of POWER SECTOR}

While the demand for electric power has been rising continuously, the generation and distribution of power has not risen proportionately. A variety of factors have affected the performance of the power sector. The contribution of conventional and non-conventional sources of energy remains relatively modest. Thermal power is generated by coal, oil and gas and also by the use of nuclear energy. Mostly thermal power is derived from coal and only a small fraction comes from oil and nuclear sources. Coal is abundant but it is concentrated in certain areas only and it is the main reason for air pollution and global warming. Due to regular mark up in oil prices, India's trade gap between imports and exports widened with every passing year, creating serious problem of adverse balance of trade and of payments. Considering the relative failure and risk of nuclear power plants, it is unlikely to make a significant contribution to power generation in the country. The generation of hydel power has been fluctuating from year to year, depending upon the nature and intensity of monsoons. Failure of monsoons adversely affects the generation of hydel power, and it takes a long-period of gestation as compared to thermal projects. Moreover there is no significant increase in the generation of renewable energy sources, because of conventional oriented energy policy.

\begin{tabular}{|c|c|c|c|c|c|c|c|c|c|}
\hline Year & $\begin{array}{c}\text { Total } \\
\text { Capacity } \\
(\mathrm{MW})\end{array}$ & $\begin{array}{c}\text { Hydro+ } \\
\text { RES } \\
\text { (MW) }\end{array}$ & $\%$ & $\begin{array}{c}\text { Thermal } \\
\text { Capacity } \\
\text { ( MW) }\end{array}$ & $\%$ & $\begin{array}{c}\text { Nuclear } \\
\text { (MW) }\end{array}$ & $\%$ & $\begin{array}{c}\text { RES } \\
\text { (MW) }\end{array}$ & $\%$ \\
\hline $1987-88$ & 60,142 & 17,265 & 29 & 41,577 & 69 & 1,300 & 2 & \multirow{19}{*}{ 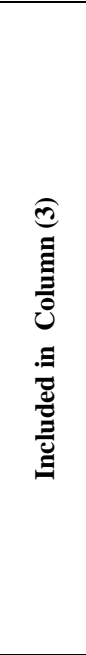 } & \multirow{19}{*}{ 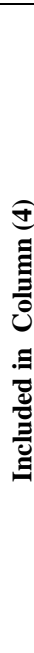 } \\
\hline $1988-89$ & 66,564 & 17,798 & 27 & 47,201 & 71 & 1,565 & 2 & & \\
\hline $1989-90$ & 72,062 & 18,308 & 26 & 52,189 & 72 & 1,565 & 2 & & \\
\hline $1990-91$ & 74,699 & 18,753 & 25 & 57,021 & 73 & 1,785 & 2 & & \\
\hline 1991-92 & 78,000 & 19,194 & 25 & 57,021 & 73 & 1,785 & 2 & & \\
\hline $1992-93$ & 82,375 & 19,580 & 24 & 60,790 & 74 & 2,005 & 2 & & \\
\hline 1993-94 & 87,475 & 20,383 & 23 & 65,087 & 75 & 2,005 & 2 & & \\
\hline 1994-95 & 83,260 & 20,950 & 25 & 60,085 & 73 & 2,225 & 2 & & \\
\hline $1995-96$ & 83,293 & 20,986 & 25 & 53,479 & 64 & 2,225 & 2 & & \\
\hline 1996-97 & 85,795 & 21,658 & 25 & 54,154 & 63 & 2,225 & 2 & & \\
\hline $1997-98$ & 89,090 & 21,891 & 25 & 64,005 & 72 & 2,225 & 2 & & \\
\hline $1998-99$ & 93,254 & 23,467 & 25 & 67,562 & 73 & 2,225 & 2 & & \\
\hline 1999-00 & 97,837 & 24,971 & 26 & 70,186 & 72 & 2,680 & 2 & & \\
\hline $2000-01$ & $1,01,166$ & 26,389 & 26 & 72,057 & 71 & 2,720 & 3 & & \\
\hline $2001-02$ & $1,05,046$ & 26,269 & 25 & 76,057 & 72 & 2,720 & 3 & & \\
\hline $2002-03$ & $1,07,877$ & 26,767 & 25 & 78,390 & 72 & 2,720 & 3 & & \\
\hline 2003-04 & $1,12,684$ & 29,507 & 26 & 80,457 & 72 & 2,720 & 3 & & \\
\hline 2004-05 & $1,18,426$ & 30,942 & 26 & 84,714 & 72 & 2,770 & 2 & & \\
\hline $2005-06$ & $1,24,287$ & 32,326 & 26 & 88,601 & 72 & 3,360 & 3 & & \\
\hline $2006-07$ & $1,32,329$ & $34,654 *$ & 24 & 88,014 & 67 & 3,900 & 3 & 7761 & 6 \\
\hline $2007-08$ & $1,43,061$ & $35,909 *$ & 25 & 91,907 & 64 & 4,120 & 3 & 11125 & 8 \\
\hline $2008-09 * *$ & $1,47,965$ & $36,878^{*}$ & 25 & 93,725 & 63 & 4,120 & 3 & 13242 & 9 \\
\hline
\end{tabular}

Source: All India Electricity Statistics General Review’ 2009 by CEA

**As on 31.03.2009*Hydro capacity only RES (Renewable) shown separately

The Table II shows the energy trend from 1987-88 to 2008-09. The type of energy includes hydro, thermal, nuclear and renewable sources in actual and percentage wise.

Table II shows generation mix of India in the form of hydro, thermal, nuclear and renewable over the years. In 1987-88 total generation mix in the power sector was 60,142 MW and it further increased to $89,090 \mathrm{MW}$ in 1997-98. Total capacity further increased in 2000-01, was 1, 01,166 and 1, 47,965 in 2008-09. It means there has been shortfall in total energy generation capacity in comparison to pre-reforms period.

The share of hydel capacity in the total generating capacity has declined from 29 percent to 25 percent at the end of 2008-09. In 1987-88, the energy generated by hydro plants was about 17,265 MW and in 2008-09 the energy generated by hydro plants increased to $36,878 \mathrm{MW}$.

Gross energy generated by hydro plants on 1987-88 was 29 percent, whereas in 2008-09 the gross energy by hydro plants was 25 percent. It is 4 percent less than the percentage of change in terms of gross energy generated by hydro plants during $1987-88$ to $2008-09$. It means significant attention is not given to hydro electric energy because of too much fluctuation in rainfall and vagaries of nature.

Thermal power generated by coal and oil has been the major source of electric power in India. Mostly thermal power is derived from coal and only a small fraction comes from oil. The energy generated through thermal plants in 1987-88 was about 41,577 MW and in 2008-09 this type of energy generated increased to $93,725 \mathrm{MW}$. The percentage change as on $2008-09$ over $1987-88$ was 63 percent. It is 6 percent less than the percentage change in terms of gross energy produced by thermal plants during 1987-88 to 2008-09.

It means that neither the public sector nor the private sector invested much in thermal means of energy production during post-reforms period. However, a thermal power station is liable to cause environmental pollution and air pollution.

Energy generated through nuclear plants in 1987-88 was about 1,300 MW and in 2008-09 the energy generated increased to 4,120 MW and its percentage change in 2008-09 over 1987-88 was 1 percent. Nuclear power generation, showed the sharpest decline, because of its radioactive waste 
disposal from the plant.

From the above table, it is understood that only a small amount of renewable sources were utilized, and it is only after 2006, renewable sources of energy was separately categorized even though it has a wide scope of potentiality.

Bibek Bandhopadhyay, advisor at the ministry of new and renewable energy said that India is a growing economy. So India's energy requirement is also growing. But India don't produce enough energy to meet even current needs. With depleting fossil fuel reserves and concerns about its environmental impact, renewable energy is the only long-term solution.

At present, India's installed power capacity is 2, 10, 645 MW with renewable energy contributing 26,900 MW or $12.4 \%$. From various energy technologies, a capacity addition of about $30,000 \mathrm{MW}$ has been planned during the 12th Plan period 2012-2017. The focus is now on mainstreaming renewable energy technologies so that it becomes cost-effective. Of this, $69 \%$ is generation from wind and $4.5 \%$ from solar. Incidentally, India was the first country to set up a ministry of non-conventional energy resources in the early 1980s.

The Government of India proposed to launch its Jawaharlal Nehru National Solar Mission under the National Action Plan on Climate Change with plans to generate 1,000 MW of power by 2013 and up to 20,000 MW grid-based solar power, 2,000 MW of off-grid solar power and cover 20 million sq metres with collectors by the end of the final phase of the mission in 2020 .

\section{Global ScENARIO OF SOLAR ENERGY}

The global cumulative installed capacity of solar photovoltaic (PV) systems reached about 15 Giga Watt (GW) during 2008, by 2013, this could reach 22 GW. Government support schemes, private funding and technological breakthroughs are some of the major factors driving solar industry. There is growing optimism that a sustained policy-driven approach could achieve grid parity in solar power in several regions worldwide. The world over, the installation of PV cells and modules has been growing at an average annual rate of 35 percent since 1998. With about 90 percent share, grid-connected applications now dominate the PV market. In the mid-1990s, this share stood at only 20 percent. At the end of 2008, more than 1,700 PV plants with a nominal capacity of $200 \mathrm{KW}$ and above were operational worldwide. More than 800 solar power plants with a capacity of $1 \mathrm{MW}$ and above have been in operation or were being tested in that year.

On a country-wise basis, growth in solar capacity has been mainly driven by Spain, Germany, Japan, the US and Italy. Germany has seen remarkable growth in the solar PV market and has reached a capacity of 5,337 MW. In Spain, installed PV capacity reached the $1 \mathrm{GW}$ level in 2008. Spain has seen significant growth in utility-scale (over 200MW) PV plants which now account for over 60 percent share in the country's PV market. A Spanish solar power developer recently built the world's largest commercial concentrated solar power station. The 50 metre tall central solar power tower comprises 624 mirrors to reflect the sun's heat and is used to turn a turbine that can produce up to $11 \mathrm{MW}$ of electricity - enough power for 6,000 homes. By 2013, it is hoped that additional towers will create a "solar farm" with an output of $300 \mathrm{MW}$, which would be enough power for 180,000 homes. The main challenge with the technology is working with extreme heat.

Other major countries with utility-scale plants include Germany, the US, Korea, Portugal and Italy. Large-scale solar-based electricity generation has also taken place through Concentrated Solar Power (CSP). There has been a recent resurgence in the CSP market due to plants being set up in Spain, the US, Israel and Portugal. Solar cell and module manufacturing has largely been dominated by the European countries, Japan and the US. In recent years, China has shown impressive growth in establishing manufacturing facilities and it is a leader in the solar energy market [8].

National Aeronautics and Space Administration (NASA) of United States was one of the first large-scale customers of solar cells for the deployment of solar-powered satellites, starting way back in the 1960s. Solar cells cost hundreds of dollars per watt then, compared to less than $\$ 4$ per watt today. Investing in the developing technology for use in outer space, NASA helped bring solar PV prices out of the stratosphere and down to earth, putting the solar industry on a path to the mainstream corporate and investment opportunity that it is today [9].

The geographical focus of solar PV manufacturing is thus gradually shifting towards developing countries such as China, India, Malaysia and Taiwan. Among other things, this is due to the perceived advantages of technical manpower and labour costs that these regions offer. The following section explains about the Indian scenario of solar energy.

\section{INDIAN SCENARIO OF SOLAR ENERGY}

India was among the first countries in the world to have launched a major programme for renewable energy in the 1970s. During the Fifth Five-Year Plan (1975-80), a specific provision was made for Research and Development (R\&D) on new and renewable sources of energy. During the Sixth Five-Year Plan (1980-85), a separate Department of Non-conventional Energy Sources (DNES) was set up in 1982. The programmatic emphasis of the DNES during the 1980s was on the development, dissemination, and demonstration of various Renewable Energy Technologies (RETs). The programme was led by government subsidies.

During the Seventh Five-Year Plan (1985-90), this programme was further intensified and major advances were made in areas such as solar thermal and solar photovoltaic among others. The renewable energy programme in India got a major boost when the DNES was upgraded to a full-fledged Ministry of Non-conventional Energy sources (MNES) in 1992. Around this time, it was realized that faster diffusion of renewable energy sources required great reliance on commercialization through fiscal rather than financial incentives involving the private sector. Thus, after the formation of the Ministry, the thrust of the programme has been on market development in order to facilitate and catalyze commercialization. India is probably the only country in the world with an independent ministry for the promotion of RETs in the energy economy of the country [10]. 
Energy in the form of heat is an important requirement in domestic, agricultural, industrial and commercial sectors of our economy. In the domestic sector, thermal energy is needed for cooking, heating water and for drying purposes. In the industrial sector there is a need for hot water for cooking to provide catering to the workers, for cleaning purposes, for different stages of production etc. In the commercial sector viz., hotels, hospitals, offices, hostels etc. need thermal energy for variety of applications like cooking, laundry and steam for sterilization, kitchen activities, washing and bathing etc. Normally, these requirements for both domestic and corporate sectors are being met by burning of coal, wood, kerosene, LPG and use of electricity. Many of these conventional sources of energy can be replaced by solar energy.

Various solar and photovoltaic devices and systems are available and are proven to be useful in the field. They have been commercialized and are finding wide and increasing applications. The benefits thus accrued through application of solar devices comprise the crux of this research study.

TABLE III: DISTRIBUTION OF RATING THE UTILITY ABOUT SOLAR DEVICE

\begin{tabular}{|c|c|c|c|c|c|c|}
\hline \multirow[t]{2}{*}{ S. No } & \multirow[t]{2}{*}{ RATING } & \multicolumn{2}{|c|}{ DOMESTIC } & \multicolumn{2}{|c|}{ CORPORATE } & \multirow[t]{2}{*}{ TOTAL } \\
\hline & & DSWH & DSSL & CSWH & CSSL & \\
\hline 1. & $\begin{array}{l}\text { Extremely } \\
\text { useful }\end{array}$ & $\begin{array}{l}200 \\
(100.0)\end{array}$ & - & $\begin{array}{l}43 \\
(100.0)\end{array}$ & $\begin{array}{l}32 \\
(74.4)\end{array}$ & $\begin{array}{l}275 \\
(92.9)\end{array}$ \\
\hline 2. & Useful & - & $\begin{array}{l}10 \\
(100.0)\end{array}$ & - & $\begin{array}{l}11 \\
(25.5)\end{array}$ & $\begin{array}{l}21 \\
(7.1)\end{array}$ \\
\hline 3. & Average & - & - & - & - & - \\
\hline 4. & Unsatisfactory & - & - & - & - & - \\
\hline 5. & Not useful & - & - & - & - & - \\
\hline \multicolumn{2}{|c|}{ TOTAL } & $\begin{array}{l}200 \\
(67.5)\end{array}$ & $\begin{array}{l}10 \\
(3.3)\end{array}$ & $\begin{array}{l}43 \\
(14.5)\end{array}$ & $\begin{array}{l}43 \\
(14.5)\end{array}$ & $\begin{array}{l}296 \\
(100.0)\end{array}$ \\
\hline
\end{tabular}

Source: Compiled by researcher from collected data

TABLE IV: MOTIVATIONAL FACTORS FOR USAGE

\begin{tabular}{|c|c|c|c|c|c|c|}
\hline \multirow[t]{2}{*}{ S.No. } & \multirow{2}{*}{$\begin{array}{l}\text { Motivational } \\
\text { Factor }\end{array}$} & \multicolumn{2}{|c|}{ Domestic } & \multicolumn{2}{|c|}{ Corporate } & \multirow{2}{*}{ Total } \\
\hline & & DSWH & DSSL & $\mathrm{CSWH}$ & CSSL & \\
\hline 1 & Subsidy & $\begin{array}{l}3 \\
(60.0)\end{array}$ & - & $\begin{array}{l}2 \\
(40.0)\end{array}$ & - & $\begin{array}{l}5 \\
(100.0)\end{array}$ \\
\hline 2 & $\begin{array}{l}\text { Space In } \\
\text { Building }\end{array}$ & $\begin{array}{l}9 \\
(47.4)\end{array}$ & - & - & $\begin{array}{l}10 \\
(52.6)\end{array}$ & $\begin{array}{l}19 \\
(100.0)\end{array}$ \\
\hline 3 & Easy to operate & $\begin{array}{l}9 \\
(100.0)\end{array}$ & - & - & - & $\begin{array}{l}9 \\
(100.0)\end{array}$ \\
\hline 4 & $\begin{array}{l}\text { Less Laborious } \\
\text { Work }\end{array}$ & $\begin{array}{l}23 \\
(88.5)\end{array}$ & $\begin{array}{l}3 \\
(11.5)\end{array}$ & - & - & $\begin{array}{l}26 \\
(100.0)\end{array}$ \\
\hline 5 & $\begin{array}{l}\text { No Loss of time for } \\
\text { Fuel collection }\end{array}$ & $\begin{array}{l}14 \\
(100.0)\end{array}$ & - & - & - & $\begin{array}{l}14 \\
(100.0)\end{array}$ \\
\hline 6 & $\begin{array}{l}\text { Scarcity and high cost } \\
\text { of LPG }\end{array}$ & $\begin{array}{l}18 \\
(94.7)\end{array}$ & - & $\begin{array}{l}1 \\
(5.3)\end{array}$ & - & $\begin{array}{l}19 \\
(100.0)\end{array}$ \\
\hline 7 & $\begin{array}{l}\text { Scarcity of } \\
\text { Electricity }\end{array}$ & $\begin{array}{l}79 \\
(64.8)\end{array}$ & $\begin{array}{l}4 \\
(3.3)\end{array}$ & $\begin{array}{l}16 \\
(13.1)\end{array}$ & $\begin{array}{l}23 \\
(18.9)\end{array}$ & $\begin{array}{l}122 \\
(100.0)\end{array}$ \\
\hline 8 & Economical & $\begin{array}{l}13 \\
(86.7)\end{array}$ & - & $\begin{array}{l}2 \\
(13.3)\end{array}$ & - & $\begin{array}{l}15 \\
(100.0)\end{array}$ \\
\hline 9 & $\begin{array}{l}\text { Inspiration } \\
\text { From others }\end{array}$ & $\begin{array}{l}12 \\
(100.0)\end{array}$ & - & - & - & $\begin{array}{l}12 \\
(100.0)\end{array}$ \\
\hline 10 & $\begin{array}{l}\text { Pollution Free } \\
\text { Environment }\end{array}$ & $\begin{array}{l}20 \\
(64.5)\end{array}$ & $\begin{array}{l}1 \\
(3.2)\end{array}$ & - & $\begin{array}{l}10 \\
(32.3)\end{array}$ & $\begin{array}{l}31 \\
(100.0)\end{array}$ \\
\hline 11 & MANDATORY & - & $\begin{array}{l}2 \\
(8.3)\end{array}$ & $\begin{array}{l}22 \\
(91.7) \\
\end{array}$ & - & $\begin{array}{l}24 \\
(100.0)\end{array}$ \\
\hline Total & & $\begin{array}{l}200 \\
(67.6)\end{array}$ & $\begin{array}{l}10 \\
(3.4)\end{array}$ & $\begin{array}{l}43 \\
(14.5)\end{array}$ & $\begin{array}{l}43 \\
(14.5)\end{array}$ & $\begin{array}{l}296 \\
(100.0)\end{array}$ \\
\hline
\end{tabular}

Source: Compiled by researcher from collected data

Table III shows the rating of utility given by the solar device users. Solar water heater is a hit among the respondents since 200 user respondents confirmed that it is extremely useful, in the domestic sector. However, in the case of street lamps, 10 user respondents find it useful. It was already evident from table 10 that domestic sector were more 
familiar only with solar water heater when compared to street lights (19 percent), the reason being attributed to operational and maintenance factors. 43 and 32 user respondents from corporate sector finds extremely useful in the case of solar water heater and solar street light. 11 user respondents in the corporate sector enjoyed usefulness of street light. No one expressed their negative views of usefulness on the usage of solar devices. This means that the satisfactory levels of the users can be enhanced through proper training methods, teaching maintenance techniques which will reduce long run depreciation rate and through easy loans and subsidy facilities. Such methods definitely will provide 100 percent satisfaction and usefulness by the users in these devices. Since none of the users are unsatisfied, it is clear that solar devices can substitute easily the other forms of non-renewable sources and still perform better than those sources. Hence, it is crystal clear that solar energy potential has a very wide scope in the days to come.

Motivation is an important variable that influences the public to adopt novel ideas. Accordingly, there have been several factors that motivated the users to install solar energy devices. The study aims at identifying such motivational factors which is presented in Table IV above. As given in Table IV the study has identified as many as eleven motivational factors prompting the users to choose solar devices. The analysis reveals that for 122 user respondents of the users motivated due to the scarcity, high cost of electricity and LPG that prompted them to switch to solar devices. It is also revealed that solar energy is pollution free environment has been the second major motivating factor among 31 user respondents. This is followed by the reasons of less laborious work and mandatory rule to use the devices respectively for 26 and 24 user respondents. Other sources of motivation such as space in building, economy, no loss of time for fossil fuel collection, inspiration from others, easy to operate and subsidy etc. have given their lending hands almost equally in motivating the respondents to install solar devices. Thus, motivation clubbed with spreading knowledge of solar devices and the basic need in increasing the educational standards of the people will help in the better understanding and utilization of solar devices by the common man.

The following tables examine the hypothesis among the two types and 500 LPD sizes of solar devices with discounted costs and discounted benefits.

Table V shows the total cost of 500 LPD Flat Plate Collector's which added with the additional and maintenance cost calculated at a discounted rate amounted to Rs. 92920.25 which is lesser than the benefit accrued (also taking into account the scrap value of the module). Therefore the module gives a profit to the individual of domestic solar uses who owns the particular module. The Table VI gives an account of costs and benefits calculated for a 500 LPD Evacuated tube Collector.

Its total cost added with the additional and maintenance cost calculated at a discounted rate for future dates amount to Rs. 87297.50 which is lesser than the benefit calculated taking into account its scrap value. Therefore it is profitable to the user respondents who have used this module in the study area.

Hence the researcher has rejected the hypothesis and accepted the alternative hypothesis; the result shows that there is a significant difference between the Flat plate collector and Evacuated tube Collector solar water heaters and its pay back periods.

TABLE V: Flat Plate COLLECTOR OF 500 LPD

\begin{tabular}{|c|c|c|c|c|c|c|}
\hline $\begin{array}{c}\text { No. of } \\
\text { Years }\end{array}$ & Total cost & Discounted Factor & Discounted Cost & Total Benefit & $\begin{array}{c}\text { Discounted } \\
\text { Benefit }\end{array}$ & B - C \\
\hline$(\mathrm{a})$ & $(\mathrm{b})$ & $(\mathrm{c})$ & $\begin{array}{c}(\mathrm{d}) \\
(\mathrm{b} \times \mathrm{c})\end{array}$ & $(\mathrm{e})$ & $\begin{array}{c}(\mathrm{f}) \\
(\mathrm{e} \text { x c) }\end{array}$ & $\begin{array}{c}(\mathrm{g}) \\
(\mathrm{f}-\mathrm{d})\end{array}$ \\
\hline 1 & 87,500 & 0.9099 & 79616.25 & 30,000 & 27297 & $-52,319$ \\
\hline 2 & 9000 & 0.826 & 7434 & 30,000 & 24780 & 17,346 \\
\hline 3 & 1000 & 0.751 & 751 & 30,000 & 22530 & 21,779 \\
\hline 4 & 1000 & 0.683 & 683 & 30,000 & 20490 & 19,807 \\
\hline 5 & 1000 & 0.621 & 621 & 30,000 & 18630 & 18,009 \\
\hline 6 & 1000 & 0.564 & 564 & 30,000 & 16920 & 16,356 \\
\hline 7 & 1000 & 0.513 & 513 & 30,000 & 15390 & 14,877 \\
\hline 8 & 1000 & 0.467 & 467 & 30,000 & 14010 & 13,543 \\
\hline 9 & 1000 & 0.424 & 424 & 30,000 & 12720 & 12,296 \\
\hline 10 & 1000 & 0.386 & 386 & 30,000 & 11580 & 11,194 \\
\hline 11 & 1000 & 0.35 & 350 & 30,000 & 10500 & 10,150 \\
\hline 12 & 1000 & 0.319 & 319 & 30,000 & 9570 & 9,251 \\
\hline 13 & 1000 & 0.29 & 290 & 30,000 & 8700 & 8,410 \\
\hline 14 & 1000 & 0.263 & 263 & 30,000 & 7890 & 7,627 \\
\hline 15 & 1000 & 0.239 & 239 & 33,000 & 7887 & 7,648 \\
\hline & & & 92920.25 & & 228894 & 135,974 \\
\hline
\end{tabular}


TABLE VI: EVACUATED TUBE COLLECTOR OF 500 LPD

\begin{tabular}{|c|c|c|c|c|c|c|}
\hline $\begin{array}{l}\text { No. of } \\
\text { Years }\end{array}$ & Total cost & $\begin{array}{c}\text { Discounted } \\
\text { Factor }\end{array}$ & $\begin{array}{c}\text { Discounted } \\
\text { Cost }\end{array}$ & $\begin{array}{c}\text { Total } \\
\text { Benefit }\end{array}$ & $\begin{array}{c}\text { Discounted } \\
\text { Benefit }\end{array}$ & $\mathrm{B}-\mathrm{C}$ \\
\hline (a) & (b) & (c) & $\begin{array}{c}(\mathrm{d}) \\
(\mathrm{b} \times \mathrm{c})\end{array}$ & (e) & $\begin{array}{c}(\mathrm{f}) \\
(\mathrm{e} \times \mathrm{c})\end{array}$ & $\begin{array}{c}(\mathrm{g}) \\
(\mathrm{f}-\mathrm{d})\end{array}$ \\
\hline 1 & 85,000 & 0.9099 & 77341.5 & 30,000 & 27297 & $-50,045$ \\
\hline 2 & 8500 & 0.826 & 7021 & 30,000 & 24780 & 17,759 \\
\hline 3 & 500 & 0.751 & 375.5 & 30,000 & 22530 & 22,155 \\
\hline 4 & 500 & 0.683 & 341.5 & 30,000 & 20490 & 20,149 \\
\hline 5 & 500 & 0.621 & 310.5 & 30,000 & 18630 & 18,320 \\
\hline 6 & 500 & 0.564 & 282 & 30,000 & 16920 & 16,638 \\
\hline 7 & 500 & 0.513 & 256.5 & 30,000 & 15390 & 15,134 \\
\hline 8 & 500 & 0.467 & 233.5 & 30,000 & 14010 & 13,777 \\
\hline 9 & 500 & 0.424 & 212 & 30,000 & 12720 & 12,508 \\
\hline 10 & 500 & 0.386 & 193 & 30,000 & 11580 & 11,387 \\
\hline 11 & 500 & 0.35 & 175 & 30,000 & 10500 & 10,325 \\
\hline 12 & 500 & 0.319 & 159.5 & 30,000 & 9570 & 9,411 \\
\hline 13 & 500 & 0.29 & 145 & 30,000 & 8700 & 8,555 \\
\hline 14 & 500 & 0.263 & 131.5 & 30,000 & 7890 & 7,759 \\
\hline 15 & 500 & 0.239 & 119.5 & 30,500 & 7289.5 & 7,170 \\
\hline \multicolumn{3}{|c|}{ Total } & 87297.5 & & 228296.5 & 140,999 \\
\hline
\end{tabular}

Source: Compiled by researcher from collected data

\section{CONCLUSION}

Solar energy cut our electricity bills. Sunlight is free, if once you have paid for the initial installation your electricity costs will be reduced. Solar electricity is green, renewable energy and doesn't release any harmful carbon dioxide or other pollutants. A typical home solar PV system could save over a tonne of carbon dioxide per year - that's more than 30 tonnes over its lifetime.

Costs have fallen significantly over the last year. They vary between installers and products, the more electricity the system can generate, the more it costs but the more it could save. Larger systems are usually more cost-effective than smaller systems (up to $4 \mathrm{kWp}$ ). It will save over a tonne of carbon dioxide every year. The result of the hypothesis and the analysis of the objectives have also proved that solar energy is a best energy for human life.

\section{REFERENCES}

[1] K. Muhopadhyay, B. Sensarma, and H. Saha, "Solar PV lanterns with Centralized charging system- a new concept for rural lighting in the developing nations," Solar Energy Materials and Solar Cells, vol. 31, pp. 437-446. 1993.

[2] A. Kumar et al., Potential of Solar Energy in India, New Delhi, Tata Energy Research Institute Publications, 1996.

[3] S. K. Chopra, Energy policy for India: Towards Sustainable Energy Security in India in the $21^{\text {st }}$ Century, New Delhi, Mohan Prinlani for Oxford \& IBH publishing co. pvt. Ltd., 2004.
[4] B. P. Banerjee, Hand Book of Energy and the Environment in India, New Delhi, Oxford University, 2005.

[5] M. Singh, "Views on energy," Economic Times, Chennai, Friday 5 June 2009, pp. 17.

[6] S. P. Gupta, India: Vision 2020, Planning Commission, Government of India, New Delhi, 2004, pp. 113

[7] Panorama Year Book, Upkar Prakashan, Uttar Pradesh, Agra 2007, pp. 183.

[8] Eropean Photovoltaic Industry Association, "Solar power trends," Power Line, vol. 13, no. 8, pp. 78, April 2009.

[9] R. Pernick and C. Wilder, The Clean Tech Revolution, New York, Harper Collins Publishers, 2007, pp. 46.

[10] Sustainable Energy Development in India, Eu - India Partnership for Technology Cooperation, New Delhi, Teri, 1999, pp. 22.

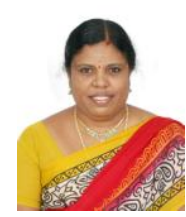

S. Chinnammai was born on July 4, 1965 in Chennai. She got the M.A, M. Phil, Ph.D., doctor of philosophy in economics, University of Madras, Chennai, Tamil Nadu, India and degree earned in 2000 on economics.

She is an associate professor in the Department of Economics, University of Madras since 2000. She published more than 20 articles in the reputed journals and books. She published two articles in Proceedings of international multi disciplinary conference on solar energy entitled on solar energy - the ray of hope and renewable energy -an Indian perspective ( Chennai, India :Excel India publisher,2012). She published a book on financial reform and new developments in banks (New Delhi, India: Serials Publications, 2010). Her works ranges across the discipline of energy, water, including various aspects of renewable energy, cost- benefit analysis in energy and field evaluation. 